\title{
FUNGSI TIM PENGAWAL, PENGAMAN PEMERINTAHAN DAN PEMBANGUNAN DAERAH (TP4D) TERHADAP PENGGUNAAN DANA DESA
}

\author{
Oleh: \\ Putu Rizky Sitraputra \\ Email:rizky.sitraputra@gmail.com \\ Jaksa Pada Kejaksaan Negeri Klungkung
}

\begin{abstract}
Duties and Functions of Central Government and Development (TP4D) and Regional Guards, Safeguards Teams (TP4D) based on the objectives of the issuance of the Attorney General's Instruction of the Republic of Indonesia Number: INS-001 / A / JA / 10/2015 namely development acceleration and strategic development programs national through assistance and escort of TP4D Attorney General of the Republic of Indonesia. The rise of misuse of village funds by the Village Head after the coming of Law 6 of 2014 concerning Villages due to the large financial management of village funds so that preventive measures are needed to reduce misuse of village funds through mentoring and escorting TP4D Prosecutors of the Republic of Indonesia.
\end{abstract}

Keyword : TP4D, Village Funds, Attorney

\section{A.PENDAHULUAN}

\section{Latar belakang Masalah}

Terselenggaranya pemerintahan yang baik, bersih, dan berwibawa menjadi cita-cita dan harapan setiap bangsa. Kejaksaan Republik Indonesia sebagai lembaga penegak hukum juga harus berperan dalam mendukung keberhasilan penyelenggaraan pemerintahan dan pembangunan nasional di pusat dan daerah melalui pengawalan dan pengamanan, baik dalam kegiatan perencanaan, pelaksanaan maupun pemanfaatan hasil pembangunan, termasuk dalam upaya mencegah timbulnya penyimpangan dan kerugian negara.

Dalam rangka mendukung penyelenggaraan pemerintahan dan pembangunan nasional di pusat dan daerah melalui pengawalan dan pengamanan, serta upaya mencegah timbulnya penyimpangan dan kerugian negara, maka Kejaksaan Republik Indonesia mengeluarkan Instruksi Jaksa Agung Republik Indonesia Nomor : INS-001/A/JA/10/2015 tentang Pembentukan

dan Pelaksanaan Tugas Tim Pengawal, Pengaman Pemerintahan dan Pembangunan Pusat (TP4P) dan Daerah (TP4D).

Dasar filosofi dibentuknya Tim Pengawal, Pengaman Pemerintahan dan Pembangunan Pusat (TP4P) dan Daerah (TP4D) adalah agenda prioritas dari Presiden RI Joko Widodo dalam menjalankan roda pemerintahan yang tercantum di dalam 9 (sembilan) Agenda Prioritas yang disebut Nawa Cita. Sebagai tindak lanjut dari 9 (sembilan) Agenda Prioritas Nawa Cita, maka Presiden mengeluarkan Instruksi Presiden Nomor 7 Tahun 2015 tentang Aksi Pencegahan dan Pemberantasan Korupsi yang dimaksudkan untuk meningkatkan upaya pencegahan terjadinya tindak pidana korupsi di Instansi Pemerintahan yang perlu didukung dan dilaksanakan secara terencana dan sungguh-sungguh sehingga kegiatan pencegahan korupsi yang dilakukan kejaksaan dapat berlangsung dengan efektif dan optimal. 
Dari adanya Instruksi Presiden Nomor 7 Tahun 2015 ini, maka Kejaksaan Republik Indonesia memandang perlu memberikan pendampingan kepada pejabat pemerintahan terkait dalam hal akselerasi pembangunan dan program-program strategis pembangunan nasional.

Perlu diketahui dengan hadirnya UndangUndang Republik Indonesia Nomor 6 Tahun 2014 tentang Desa menandai dimulainya era menuju kemandirian desa sejalan dengan hal tersebut pemerintah mengucurkan dana desa yang ditujukan untuk meningkatkan kesejahteraan masyarakat di desa sehingga diperlukan kemampuan aparatur desa untuk mengelola keuangan desa yang baik dan benar. ${ }^{1}$

Sejak 5 (lima) tahun pasca dibentuknya Undang-Undang Desa, pengelolaan penggunaan dana desa belum optimal dan sering terjadi penyalahgunaan dana desa oleh kepala desa atau perbekelnya. Sebagai contoh: Kasus Penyalahgunaan Pengelolaan APBDes Desa Satra sebesar Rp 1.430.000.000 (satu milyar empat ratus tiga puluh juta rupiah) yang dilakukan oleh Ni Made Ratnadi selaku Kepala Desa Satra. Dimana rencananya Dana APBDes itu akan dipakai untuk menunjang Program dibidang penyelenggaraan pemerintahan desa sebesar $\mathrm{Rp}$ 653.000.000,- (enam ratus lima puluh tiga juta rupiah), bidang pembangunan sebanyak $\mathrm{Rp}$ 273.800.000,- (dua ratus tujuh puluh tiga juta delapan ratus ribu rupiah), bidang pembinaan kemasyarakatan sebanyak Rp 36.000.000,- (tiga puluh enam juta rupiah) dan di bidang pemberdayaan masyarakat sebanyak $\mathrm{Rp}$ 469.700.000,-(empat ratus enam puluh sembilan juta tujuh ratus ribu rupiah).

Bahwa sesuai Undang-Undang Desa maupun Peraturan Menteri Dalam Negeri tentang Pengelolaan Keuangan Desa, perbekel atau kepala desa merupakan pengelola dan penanggungjawab keuangan tertinggi di desa. Dalam hal itu secara khusus Pasal 35 ayat (3) Permendagri Nomor 113 Tahun 2014 tentang Pengelolaan Keuangan Desa juncto Pasal 35 ayat (3) Perbup Klungkung Nomor 23 Tahun 2015 tentang Pengelolaan Dana Desa menyebutkan bahwa yang berkewajiban untuk membuat laporan pertanggungjawaban mengenai penggunaan dana desa adalah bendahara bukan perbekel. Namun perbekel desa satra melanggarnya dengan modus Surat Pertanggungjawaban atau SPJ dana-dana desa dalam APBDes justru dibuat sendiri olehnya yang kemudian diserahkan kepada bendahara untuk selanjutnya dilaporkan dalam LPJ tahunan.

Berdasarkan pemaparan diatas, sangat menarik untuk dibahas lebih lanjut mengenai fungsi Tim Pengawal, Pengaman Pemerintahan Dan Pembangunan Daerah (TP4D) Terhadap Penggunaan Dana Desa.

\subsection{Rumusan Masalah}

1. Apakah Tugas dan Fungsi Tim Pengawal Pengaman Pemerintahan dan Pembangunan Daerah (TP4D)?

2. Apakah Pendampingan Penggunaan Dana Desa termasuk fungsi Tim Pengawal, Pengaman Pemerintahan Dan Pembangunan Daerah (TP4D)?

\section{A. PEMBAHASAN \\ 1. Tugas dan Fungsi Tim Pengawal Pengaman Pemerintahan dan Pembangunan Daerah (TP4D)}

Berdasarkan Keputusan Jaksa Agung Republik Indonesia Nomor: KEP-152/A/JA/10/ 2015 tentang Pembentukan Tim Pengawal, Pengaman Pemerintahan dan Pembangunan Daerah (TP4D) Kejaksaan Republik Indonesia. Tim Pengawal, Pengaman Pemerintahan dan Pembangunan Daerah (TP4D) mempunyai tugas dan fungsi sebagai berikut:

1. Mengawal, mengamankan dan mendukung keberhasilan jalannya pemerintahan dan pembangunan melalui upaya-upaya pencegahan/preventif dan persuasif baik ditingkat pusat maupun daerah sesuai wilayah hukum penugasan masing-masing dengan caracara :

a) Memberikan penerangan hukum di lingkungan instansi pemerintah, BUMN, BUMD, dan pihak lain terkait materi tentang perencanaan, pelelangan, pelaksanaan pekerjaan, 
pengawasan pelaksanaan pekerjaan, perijinan, pengadaan barang dan jasa, tertib administrasi dan tertib pengelolaan keuangan negara.

b) Melakukan diskusi atau pembahasan bersama instansi pemerintah, BUMN, BUMD untuk mengidentifikasi permasalahan yang dihadapi dalam penyerapan anggaran dan pelaksanaan pembangunan.

c) Memberikan penerangan dan penyuluhan hukum baik atas inisiatif TP4D maupun atas permintaan pihak-pihak yang memerlukan yang tempat dan waktu pelaksanaannya ditetapkan berdasarkan kesepakatan dan sesuai kebutuhan.

d) TP4D dapat melibatkan instansi atau pihak lain yang memiliki kapasitas, kompetensi dan relevan dengan materi penerangan dan penyuluhan hukum yang akan disampaikan kepada instansi pemerintah, BUMN, dan BUMD.

2. Dapatmemberikan pendampingan hukum dalam setiap tahapan program pembangunan dari awal sampai akhir, berupa:

a) Pembahasan hukum dari sisi penerangan, regulasi, pengaturan perundang-undangan, mekanisme dan prosedur dengan pejabat pengelola anggaran atas permasalahan yang dihadapi dalam hal penyerapan anggaran.

b) Pendapat hukum dalam tahapan perencanaan, pelelangan, pelaksanaan pekerjaan, pengawasan pelaksanaan pekerjaan, pengadaan barang dan jasa baik atas inisiatif TP4D maupun atas permintaan instansi dan pihak-pihak yang memerlukan.

3. Melakukan koordinasi dengan Aparat Pengawasan Intern Pemerintah untuk mencegah terjadinya penyimpangan yang berpotensi menghambat, menggagalkan dan menimbulkan kerugian bagi keuangan negara.

4. Bersama-sama melakukan monitoring dan evaluasi pelaksanaan pekerjaan dan program pembangunan.

5. Melaksanakan penegakan hukum represif ketika ditemukan bukti permulaan yang cukup setelah dilakukan koordinasi dengan Aparat Pengawas Intern Pemerintah tentang telah terjadinya perbuatan melawan hukum, penyalahgunaan kewenangan dan/atau perbuatan lainnya yang berakibat menimbulkan kerugian bagi keuangan negara.

\section{Fungsi Tim Pengawal, Pengaman Pemerintahan Dan Pembangunan Daerah (TP4D) Terhadap Penggunaan Dana Desa.}

Bahwa berdasarkan tujuan dari dibentuknya Tim Pengawal, Pengaman Pemerintahan dan Pembangunan Daerah (TP4D) yaitu memberikan pendampingan kepada pejabat pemerintahan terkait dalam hal akselerasi pembangunan dan program-program strategis pembangunan nasional sebagaimana amanat Instruksi Presiden Nomor 7 Tahun 2015 tentang Aksi Pencegahan dan Pemberantasan Korupsi. Oleh karena itu sebenarnya pendampingan dam pengawalan terhadap penggunaan dana desa tidak termasuk program strategis pembangunan nasional yang perlu dikawal oleh Tim Pengawal, Pengaman Pemerintahan dan Pembangunan Daerah (TP4D) Namun demikian terhadap aparatur desa yang ingin berkoordinasi dengan Tim Pengawal, Pengaman Pemerintahan Dan Pembangunan Daerah (TP4D) sehubungan Penggunaan Dana Desa tentunya dapat melakukan permohonan untuk kemudian dilakukan pemaparan untuk mengetahui permasalahan yang dihadapi sehingga dapat diberikan pendapat hukum (legal opinion) oleh Kejaksaan pada bidang perdata dan tata usaha negara (datun) sehingga penggunaan dana desa bisa terserap dengan optimal.

Faktor yang mempengaruhi pelaksanaan tugas dan fungsi kejaksaan sebagai tim pengawal dan pengaman pemerintahan dan pembangunan daerah (TP4D) dalam upaya menanggulangi tindak pidana korupsi:

a. Faktor hukumnya sendiri dimana dengan adanya aturan mengenai TP4D maka memudahkan bagi kejaksaan dalam melakukan pencegahan tindak pidana korupsi namun belum adanya aturan yang setara undangundang hanya INPRES dan PERJAM yang 
mengakibatkan TP4 tidak bersifat mengikat dan tidak tunduk sepenuhnya pada TP4D.

b. Faktor penegak hukum dimana anggota TP4D tidak bisa bergerak langsung tanpa harus adanya permohonan, dimana kinerja TP4D menjadi kurang maksimal.

c. Faktor komunikasi dimana sangat penting komunikasi yang baik antara kejaksaan dengan pihak pemohon dengan itu diharapkan pihak pemohon secara terbuka memaparkan permasalahan yang ada dalam instansi pemerintah tersebut. maka dari itu kejaksaan dengan mudah memberikan pendapat hukum kepada pihak pemohon tersebut.

d. Faktor masyarakat yaitu masyarakat masih banyak yang belum mengetahui tentang TP4 jadi pada saat ini tim TPD4 Kejaksaan Negeri Denpasar sedang gencar melakukan sosialisasi tentang TP4D.

e. Faktor kebudayaan, yakni budaya korupsi yang tinggi dimana adanya proyek yang bernilai besar namun tidak dimohonkan untuk adanya pengawalan oleh tim TP4 Kejaksaan.

\section{B. PENUTUP}

\section{a. Simpulan}

1. Tugas dan fungsi Tim Pengawal, Pengaman Pemerintahan dan Pembangunan Daerah (TP4D) adalah Mengawal, mengamankan dan mendukung keberhasilan jalannya pemerintahan dan pembangunan melalui upaya-upaya pencegahan/preventif dan persuasif.

2. Fungsi Tim Pengawal, Pengaman Pemerintahan Dan Pembangunan Daerah (TP4D) Terhadap Penggunaan Dana Desa melakukan telahaan dan kajian atas permohonan dari Perbekel atau Kepala Desa sehubungan dengan penggunaan dana desa apakah termasuk kategori program strategis nasional sebagaimana amanat Instruksi Presiden Nomor 7 Tahun 2015 sehingga dapat diketahui dapat atau tidaknya dilakukan pendampingan.

\section{b. Saran}

1. Perlunya dilakukan sosialisasi oleh Tim Pengawal, Pengaman Pemerintahan dan
Pembangunan Daerah (TP4D) berkaitan dengan tugas dan fungsinya agar masyarakat dapat mengetahui.

2. Sebaiknya Kejaksaan dapat melakukan Mou terhadap desa-desa melalui bidang Perdata dan Tata Usaha Negara sehubungan dengan pemberian pendapat hukum (legal opinion) pemanfaatan penggunaan dana desa.

\section{DAFTAR PUSTAKA}

\section{BUKU.}

Ginandjar Kartasasmita, 2001, Pembangunan Untuk Rakyat: Memadukan Pertumbuhan Dan Pemerataan, Pustaka Cidensindo, Jakarta Akmal, 2010, Untung dan Buntungnya Pajak final: Kajian Mengenai Keuntungan dan Kerugian/ Kelemahan Sistem Pengenaan Pajak Penghasilan Final, Gramedia, Jakarta

\section{PERATURANPERUNDANG-UNDANGAN}

Undang-Undang Nomor 16 Tahun 2004 Tentang Kejaksaan.

Instruksi Presiden Nmor 7 Tahun 2015 tentang Aksi Pencegahan dan Pemberantasan Korupsi Tahun 2015.

Keputusan Jaksa Agung Republik Indonesia Nomor: INS-001/A/JA/10/2015 tentang Pembentukan dan Pelaksanaan Tugas Tim Pengawal dan Pengaman Pemerintahan dan Pembangunan Pusat dan Daerah Kejaksaan Republik Indonesia

\section{(Footnotes)}

${ }^{1}$ Ginandjar Kartasasmita, 2001, Pembangunan Untuk Rakyat: Memadukan Pertumbuhan Dan Pemerataan, Pustaka Cidensindo, Jakarta, hlm. 45. 